SCJR 11, no. 1 (2016): 1-3

\title{
Mary Marshall \\ The Portrayals of the Pharisees \\ in the Gospels and Acts
}

(Göttingen: Vandenhoeck \& Ruprecht, 2015), hardcover, 265 pp.

\author{
AMY-JILL LEVINE \\ amy-jill.levine@vanderbilt.edu \\ Vanderbilt University, Nashville, Tennessee 37240
}

In this revision of her 2009 Oxford dissertation (directed by Christopher Tuckett), Marshall demarcates the portrayals of the Pharisees in the canonical Gospels and Acts. She correctly notes that the Christian tendency to view the Pharisees wholly negatively has led to the underestimation of the complexity of their portrayals in the New Testament. Marshall shows how the evangelists display distinct redactional concerns regarding not only Pharisees and complementary Jewish topics including Torah and Temple, but also issues of Christology, ecclesiology, ethics, and discipleship.

Several methodologically perceptive moves mark the work. Marshall does not, "in the absence of adequate justification to the contrary, suppose that either the authors or their readers possessed any substantial or first-hand knowledge of the Pharisees" (p. 24). Therefore, she offers literary-critical observations unhampered by debates about the authors' historical presumptions. She also cogently both guards against regarding the Pharisees as necessarily engaged in "supererogatory purity" (p. 38) and diminishes claims, based on questionable historical reconstruction, that the Pharisees are promoting Judean nationalism as opposed to, for example, personal piety, correct interpretation of Torah, or reactions to Christological teachings. Cautions regarding scholarly use of the birkhat haminim to explain the polemics, especially in the Gospels of Mark and John, are well taken, as is her wariness of reading the Fourth Gospel, following J.L. Martyn's hypothesis, as a two-tiered story in which the narrative recapitulates John's historical situation.

Marshall's literary-critical observations also cut through scholarly apologetics seeking to diminish the Pharisees' negative portraiture in the New Testament. For example, she concludes for Mark, "It is difficult to uphold the suggestion that the significance of the Pharisees' opposition is mitigated by their absence from the events of Jesus' passion" (p. 67). Confirming the consensus that Matthew heightens Mark's negative portrayal of the Pharisees, she further finds that Matthew's Pharisees do not simply repeat the negative depictions of the chief priests, scribes, and elders, but that they are "opponents in their own right" (p. 79). She 
also argues that Matthew enhances the divisiveness of their disputes with Jesus over the issue of defilement, and she notes that Mark highlights debates over Christology and the source of Jesus' authority, while Matthew focuses on halakhic concerns.

For the Fourth Gospel, Marshall argues that John's use of "Pharisees" along with the broader category of Jews / Judaeans (Ioudaioi) creates both distinctions and overlaps. Her point that John's Pharisees are more concerned to note the reactions of others to Jesus rather than to offer reactions to Jesus himself is a keen insight (p. 205). Generously, she proposes that the Pharisees' question to Jesus, "Surely we are not blind, are we?" (Jn 9:40) "may be interpreted as a genuine appeal for clarification and reassurance" (p. 191). For John, however, the question is comparable to Pilate's equally benighted and dismissive query, "I am not a Jew, am I?" (Jn 18:35). The answer to both questions, in terms of Johannine symbolism, is "yes." While she shows that the Pharisees cannot be completely subsumed into the broader category of "Jews" (Ioudaioi), and while her thematic rather than plot-based approach does heighten the distinctions, readers more attentive to plot and so to narrative flow might conclude that by the end of the Gospel, such distinctions disappear.

The most innovative aspect of the study is the appeal to distinct characterizations of the Pharisees in Luke and in Acts. In the Gospel, the Pharisees are not individualized, but Acts introduces Gamaliel and Paul. In the Gospel, the Pharisees remain outsiders, but in Acts they are found inside the Church. Thus Marshall supports the view that the Gospel presentation does not constrain the depiction of the Pharisees in Acts. How, exactly, the depictions of these individual Pharisees depart from the Gospel's largely negative portraits remains debated. That "the Pharisees' role as defenders of the church is confirmed by the fact that Luke nowhere explicitly suggests their involvement in any of the arrests and martyrdoms of Christians" is technically correct, since the earlier parts of Acts do not mention Paul's Pharisaic background (p. 146). However, a second reading of Acts finds Paul the Pharisee (Acts 23:6; 26:5) "approving" of Stephen's death (Acts 8:1) and "ravaging the church" (Acts 8:3). Gamaliel defends Peter and John, and Paul the persecutor was Gamaliel's student (Acts 22:3). Yet Paul's Pharisaic teacher, who compares Jesus to Theudas and to Judas the Galilean (Acts 5:36-37), may be less benevolent than Marshall suggests. Similarly, the Pharisees in the Christian community remain negative foils who insist that Gentile members "be circumcised and ordered to keep the law of Moses" (Acts 15:5). In Acts, Paul emerges as the only Pharisee, and perhaps the only Jew, who displays correct Jewish piety.

At times, Marshall reinstantiates rather than interrogates stereotypes of Pharisees. She categorizes "tax collectors and sinner" as "outcasts [and] archetypes of disreputability" (p. 38; see also pp. 93, 179) who were rejected by Pharisees. Sinners and tax collectors are not "outcasts"; they rather walked out of the covenant community in favor of personal gain. The people in Mt 9, to whom Jesus "has shown mercy and compassion by turning towards outcasts," are not cast out from anything: most (e.g., a paralytic, Jairus' daughter) are embedded in a familial con- 
text (p. 93). The paralytic is not cast out, but is rather cast in, when his friends open a roof to lower him to Jesus. The hemorrhaging woman and the demoniac are not seen as stripped of social relations. Marshall finds that for Luke, the Pharisees are those who "shun the sinners who have sought forgiveness" (p. 137 see also p. 179). But such repentance is not explicit. Simon the Pharisee could not know that the "woman from the city who was a sinner" (Lk 7:36) repented; the Pharisees remark that Jesus dines with "sinners and tax collectors" (Mt 9:10-11; Mk 2:15-16; Lk 5:30; 15:1-2), yet no mention is made of their repenting.

In other cases, Marshall's claims regarding historicity outstrip the evidence, despite her care to avoid importing external reconstructions. While she finds that Matthew's polemic “indicates an opposition that transcends the literary sphere and responds to opposition faced by the evangelist" (p. 124), there is no confirmatory evidence of this claim. Matthew remained the early Church's most popular Gospel, as determined by manuscript attestation, citation by the Church Fathers, and even canonical placement, but there is no reason to presume that this popularity resulted from external Jewish competition. Mirror-reading is always speculative, and Marshall misses the possible distinction between perceptions that one is being persecuted for one's beliefs and actual persecution, or received tradition vs. current status.

Marshall observes that "there is no recent and full length work by a single author that treats the Pharisees in all four Gospels and Acts" (p. 20). Is there need for one? The answer is "yes." Marshall provides in one volume a lucid description of how the Pharisees function narratively in each Gospel. Her thematic approach reveals details not easily derived from historical or plot-based efforts. Further, given shifts in scholarly source-critical views, such as the increasingly popular claim that John is familiar with some if not all of the Synoptics and is attempting to control communal memory, her volume provides the data, neatly organized, with which to assess such claims. 